\begin{tabular}{|l|l|l|}
\hline \multicolumn{2}{|c|}{ PublisherInfo } \\
\hline \hline PublisherName & $:$ & BioMed Central \\
\hline \hline PublisherLocation & $:$ & London \\
\hline \hline PublisherImprintName & $:$ & BioMed Central \\
\hline \hline
\end{tabular}

\title{
Pediatric Critical Care Medicine Website Reviewed
}

\begin{tabular}{|l|l|l||}
\hline \multicolumn{2}{|c||}{ ArticleInfo } \\
\hline \hline ArticleID & $:$ & 4230 \\
\hline \hline ArticleDOI & $:$ & $10.1186 /$ ccf-1999-webreport2 \\
\hline \hline ArticleCitationID & $:$ & webreport2 \\
\hline \hline ArticleSequenceNumber & $:$ & 18 \\
\hline \hline ArticleCategory & $:$ & Web report \\
\hline ArticleFirstPage & $:$ & 1 \\
\hline \hline ArticleLastPage & $:$ & 2 \\
\hline \hline & & RegistrationDate : 1999-5-20 \\
ArticleHistory & $:$ & OnlineDate \\
\hline \hline ArticleCopyright & $:$ & Current Science Ltd1999-5-20 \\
\hline \hline ArticleGrants & $:$ & \\
\hline \hline ArticleContext & $:$ & 1305433 \\
\hline \hline
\end{tabular}




\section{Overview}

The site includes the following sections: Clinical and research resources, Organizations and meetingscalendar, Job opportunities, Internet resources and parent resources.A special feature of the site feature is a complete educational guide to Evidence BasedMedicine (EBM) and a very well organized evidence based journal club whereclinical trials dealing with pediatric as well as adult intensive carearguments are critically reviewed in a systematic fashion to encourage the EBMapproach to the medical literature and to provide an easier interpretation offigures and data.

\section{Other comments}

28 April 1999

\section{Evaluation}

Free access available to the full text of the critical reviews and originalarticle abstracts.

\section{References}

1. Pediatric Critical Care Medicine Website. [http://PedsCCM.wustl.edu/]

This PDF file was created after publication. 